\title{
Living in the townships: An appraisal of Pentecostal social ministry in Tshwane
}

\begin{abstract}
Author:
Victor Molobi ${ }^{1}$

Affiliation:

${ }^{1}$ Research Institute for

Theology and Religion, University of South Africa,

South Africa

Note:

This article forms part of the special collection on

'Doing urban public theology in South Africa: Visions, approaches, themes and practices towards a new agenda' in HTS Teologiese Studies/Theological Studies Volume 70, Issue 3, 2014. The collection is the result of the project 'Urban Public Theology', which was initiated by the Institute for Urban Ministry but later expanded to include several academic departments and institutes at the University of Pretoria (UP) and University of South Africa (UNISA).

The leading centres in this regard were the Centre for Contextual Ministry (UP) and the Research Institute for Theology and Religion (UNISA).
\end{abstract}

\section{Correspondence to:}

Victor Molobi

Email:

molobvs@unisa.ac.za

Postal address:

PO Box 392, University of South Africa, Pretoria 0003, South Africa

\section{Dates:}

Received: 17 July 2014

Accepted: 06 Aug. 2014

Published: 20 Nov 2014
This article offers an appraisal of the social ministry of Pentecostal churches through fellowship, healing and livelihood creation in the township communities of the city of Tshwane. In meeting this aim the discussion advances a thesis of these churches as agents of social support and survival of the downcast. In particular, the article attempts to show how these churches exert themselves towards establishing not only moral responsibility, but also a context where the weakest and the least privileged can learn how to survive. The squatter camp people are unique with the special challenges requiring distinctive consideration. Pentecostal churches believe that the lost people matter to God and are of importance to their congregations as well. The backyard Bible study ministries and mutual cooperation strategies are employed for mutual support. Making use of the existing empirical research data and available literature will show how Pentecostal churches in the townships support the laity and community in times of need.

\section{Introduction}

The existence of the Pentecostal churches in the townships is not an obvious one. Many of these churches have existed in these semi-urbanised areas for a long time. Many developments and stabilities of how they function are obvious. Today, many people are talking about Pentecostalism from the 1960s until 1994 as the old face and beyond to the present as the era influenced by modernity. Unfortunately, whatever is assessed from the poverty perspective has no modern or primitive perspective as people are supposed to live above poverty margins every time.

This article defines the meaning of the township and squatters as the sister development in the urban situation in general. The article also investigates Pentecostalism not in isolation, but on how is integrated within the urban phenomenal system. You cannot define the church in the township situation without outlining the problems and the experiences there as the root of the argument. Shorter (1991) summed it well when stating that:

Memberships of younger generations of today display a frenzied urban bias, while the church struggle to lethargically shake off its load from anti-Urbanism. Both extremes of urban bias and anti-urbanization are unrealistic in the circumstances. Urbanization is not decided by people, but it is determined by the economic factors such as industrial planning and development. As a result urbanization is a reality that cannot be ignored. (p. 137)

In a way urbanisation is part of human history, human culture and human economic development. On the one hand, it has its own disadvantages in the areas where it has developed. It often forces the tensions between producers and products that lead to systematic injustice developments with various squabbles amongst the workers. Urbanisation therefore becomes an urgent life and death issue for human society and for the Christian Churches as well.

It is useless for the priest or the pastor, the missionary or the church worker, the catechist or the community leader, to tread water, as it were, whilst waiting for life saver to appear on the beach. They must strike out at once for the shore. In other words, it is not good waiting for an urban specialist to drop in to cope with these new problems (Shorter 1991:138). The urban and township dwellers are usually the only available specialists who supposed to confront the gigantic dilemma that urbanisation poses in the world of today.

How do Pentecostal churches in Tshwane townships address the social challenges there? How do they attempt to deal with different groups of people in the urban and black townships around the cities? The age groups, gender, social hierarchy and economic well-being will be viewed inclusively, simply because of lack of space to address them in detail individually, but will be approached with consideration for the Pentecostal position.

How to cite this article: Molobi, V., 2014, 'Living in the townships: An appraisal of Pentecostal social ministry in Tshwane', HTS Teologiese Studies/Theological Studies 70(3), Art. \#2791, 9 pages. http://dx.doi.org/10.4102/hts.v70i3.2791

Copyright: ๑ 2014. The Authors.Licensee: AOSIS OpenJournals. This work is licensed under the Creative Commons Attribution License. 
In most cases the townships are comprised of poor people. To make this discussion interesting we will view the problems from the people's voices in and outside the church. We will also measure the attitudes of Pentecostal assemblies in the towns and the degrees of changes they brought in addressing the people's troubles in the urban townships over the age.

Most importantly, we will likewise want to recognise whether they indicate any changes or they stay the same. What are the poor communities' hopes and concerns? Lastly, we will investigate which of these problems people think that Pentecostal members can solve or are helping to solve in the towns.

\section{Problems of churches in the cities}

Before adventuring in answering the formulated questions, I will paint a picture of the problems which urban and black townships in Tshwane experience, accompanied by a subtheme discussion of the Pentecostals as institutions. This will help us to recognise exactly what can be assessed in them and how it is starting to be executed. Already by 1974 the problems of urbanisation and township crisis were accurately forecast. Albers (1974) identified the following as the principal challenges of the urban city situations:

The upsurge in population, the growth of pollution, the sprawl of urbanization, the problems of race, international and internal warfare, and omnipresent poverty, the deficiency of adequate housing, the transportation debacles, consumer welfare, the youth revolution, and the women's rights movement were some of the daily news headlines in media and newspapers. (p. 288)

Many of these problems are interrelated both in terms of causation and solution. In some instances; the taking of action in one focal point will cause difficulty in another. On that point are no readily apparent remedies for many of these problems that are causing a negative impact on humans. This discussion should not be considered as the total analysis of the state of affairs.

Albers said that the problems such as traffic congestions, crime in the streets, and deficiency of public inspection and repairs, inadequate housing, poverty, and pollution have all combined to complicate the situation (1974:290). All of these become the period of interest to many students interested in urban studies, likewise from a theological position. For example, Shorter (1991:138), a theologian, discovered that urbanisation is the most important social reality in Africa and South Africa. His judgement is that the Christian Evangelisation must take full account in solving the troubles.

It is interesting that whilst the church of Christ is perceived to be unitary, it is divided into doctrines. Every denominational sector will operate under the influence of its surroundings. Now religion has probably become slightly less important, especially since 1994 when Christianity was seen as equal with other faiths in the nation. This is taking place in spite of the large membership in the Pentecostal Christian circles. In some circuits, churches are becoming more of the business ploy than the expected charismatic support to the hardpressed people. Pentecostal and Charismatic churches are however known to be efficient and fruitful with emphasis on prayer, healing and exorcisms (Ragoonath 2004:11).

The issue is whether the churches in the urban areas are relevant to the issues of impoverishment in the midst of plenty and certainly this cannot be snubbed. It may appear paradoxical to recommend a cut back economic growth when so much poverty still persists. Albers (1974) has a point when indicating that:

More economic growth will not solve the problem if the cost of that growth is even higher levels of environmental pollution. Poverty is to a great extent a matter of income distribution which is in turn a product of problems such as deficiencies in education and skills, racial and other forms of discriminations and lack of motivation. (p. 290)

The answer to these troubles is more difficult and the matter is even more perplexed by other developments of poverty like urban slums and crime. Before we live deep into the Pentecostal discussion, we have to get this brief researched and self-observation into consideration about the profile of the churches in urban townships situations in the light of immigration.

\section{Synopsis and interest of immigrants in the Gauteng cities}

Nowadays there is a great influx of Africans into South Africa townships for different causes. This was justified by Mohammed Allie (2014) when stating that:

South Africa's townships have been a magnet for immigrants in recent years, with many of those coming to Africa's second largest economy to set up little family businesses in bustling townships.

For instance, the Nigerians are interested in training, better engagement, particularly in quality institutions of higher learning, they team up to establish churches in the cities and make fortunes out of them in the name of healing and miracles. The Senegalese and other Nigerians are Mechanics in the outer boundaries of city centres including Tshwane, whilst many South African urban and township communities' grumble about these congestions and lack of space for accommodation. The regime understands it as the opportunity for bringing in new skills. The Centre for Development and Enterprise (CDE) view the restriction on immigrants as a fault. According to them, South Africa requires a clean cut and unambiguous policy, strongly defended by understanding and arguments which are backed by all members of the Cabinet. All the restrictions on skilled immigrants must be withdrawn.

The trouble with this suggestion for South African local urban township dwellers is that South African community has for a very long time not been exposed to viable economic adventures for success. It is true that people who are arriving from outside the state has more accomplishments. Taking from those masses will constantly be faced with jealousy by the locals that do not possess such skills. Regrettably, 
whatever course of resistance will be regarded xenophobia which the local government, non-governmental organisations (NGOs), churches and the international community negates.

Ethiopians and Pakistanis are interested in the Spaza Shops businesses and are successful ${ }^{1}$ in the poor South African townships and poor rural areas. Malawians, Mozambicans and Zimbabweans are interested in jobs like constructions and gardening in the city suburbs. If there is no employment anything anywhere can be a substitute, as long as is a job and it pays some salary. Apart from this highlight, locals also have their own challenges. They need employment in society to sustain their households. Can Pentecostals have an issue in trying to offer solutions? The next sections will try to address these questions as well.

\section{Pentecostalism as an institution}

In 2008 The Apostolic Faith Mission of South Africa (AFM of SA) celebrated its 100th centennial and its President Isak Burger and Marius Nel wrote a script entitled 'The fire falls in Africa'. Chapter fifteen discusses the 'the black section of the AFM of SA' from 1958 to 1996. Morphological evolution of the church earlier was organised in such a way that the story of the black section was paternalistic controlled by white people, it was as well the history of the mother church taking care of the daughter church with goodwill and through the investment of time and finances (Burger \& Nel 2008a:220).

Agreeing to the AFM of SA constitution, then, the local preachers received authority to preach the gospel, lay hands on the sick and bury the dead. The deacons consecration of children was added, the evangelists in administering the Lords Supper and baptise believers. The ministry was itinerant and subject to the oversight of the elders where they were ministering. Seniors were in charge of the assembly, plus the ministry as evangelists. Overseers in addition to all the foregoing had the force to conduct marriage ceremonies, exercise discipline and to ordain ministers subject to the commendation of the Executive Council (Burger \& Nel 2008a:220-221). This is to indicate that earlier AFM of SA (main Pentecostal church) in South Africa then, was homogeneous, though with racial influence.

It is at this point that Indigenous Pentecostals emerged with a different approach that has combined the Zion perspective with the Apostolic one. The reason for bringing up the Pentecostal of the mainline churches is not proposing that they are better, merely that they constituted the origins or the breakpoint from the Pentecostal ties with the indigenous views on the Holy Spirit. As a result the emphasis in this clause may seem every bit as if one is choosing sides but not. The stronger Pentecostal swing is presently at the mainline levels given that it is also international and its growth needs to be observed from those stories as well.

1.Reasons for success according to Rory Liedeman, senior researcher, Sustainable Livelihoods is their social networks, which provide them with access to labour and capital and enable collective purchasing and market domination (see Econ $3 \times 3,08$ July 2014; http://www.polity.org.za).

\section{Early Pentecostal churches in South Africa}

Pentecostalism was brought to South Africa by John G Lake in 1908. It was initially circulated by the Apostolic Faith Mission (AFM) of South Africa, The Full Gospel Church of God in South Africa and the Assemblies of God (Hollenweger 1988:121-122). It arrived as a prototype of the same way in America. Having brought up only three trends of this movement, there are nevertheless many others in South Africa. Amongst others are the Pentecostal Church of Christ; Pentecostal Free Will Baptist; Pentecostal Holiness Church (Hollenweger 1988:411-451). All of these churches had influence from America. The following paragraphs will explain that in brief.

In America many ministers of traditional churches were made cognisant of the Pentecostals and their message by television broadcast of oral Roberts, the healing campaign of T.L Osborn, W Brenham, and others by the rapid development of the Pentecostal communities and the evangelisation to drug addicts and by intermediary organisations like the Full Gospel Business Men's Fellowship (FGBMFI). ${ }^{2}$

Despite vigorous criticism, the mass meetings made ministers wonder why churches were unsuccessful in interesting the 'little people,' the blue and white collar workers, ${ }^{3}$ in their services. At the banquet of the Full Gospel Business Men's Fellowship they were taken together with Pentecostals in a context that fitted their place in society. In searching so to move sociologically beyond the stage of the sect, the Pentecostals made conversion very easy, and as a result, many ministers took over Pentecostal ideology and experience uncritically (Hollenweger 1988:6).

In South Africa, since apartheid debarred black and white Pentecostals to fellowship together, the township groups developed their own way of society with the same foreign Pentecostal doctrine but influenced by the local cultures. Between 1960 and 1980 for instance, Pastor Richard Ngidi ${ }^{4}$ of the Apostolic Faith Mission of South Africa, Pastor Nicholas Bhengu $\mathrm{u}^{5}$ of the Assemblies of God were known as the stylish preachers amongst the black people, especially township dwellers. Their messages of healing, baptism and conversion, had emphasis on the Holy Spirit, and they also became prominent in the white residential districts.

When living in Lamontville in Durban in 1956, Ngidi attended a gospel crusade of renowned evangelist Bhengu, known as the 'Back to the Gospel Team'. Bhengu was not very demonstrative in his prophesying, but when he prayed for the people, the power of God was demonstrated with the sick people being healed and spiritually oppressed set free.

2.See Econ 3x3, 08 July 2014 (http://www.polity.org.za).

3.Blue collar is referring to a working class persons, historically defined by hourly rates of pay and manual labour (see Investopedia n.d.).

4.Dr Khathide (1993:48-50) writes: 'Some healing occurred during the ministry of Richard Ngidi.'

5.Bhengu, on the other hand, because of his communist interest background was prominent in healing of the sick; baptism of the Spirit, his charismatic approach, prominent in healing of the sick; baptism of the Spirit, his charismatic approach,
his concern on social ethics has made him very prominent in the black townships in South Africa. 
Richard Ngidi gave his heart to the Lord and became a new man (Berger \& Nel 2008:94).

\section{Contemporary evangelical archetypes}

By far the predecessors of Pentecostal initiatives left the incredible indelible mark in the wider black society in South Africa till today. They owned several black prototype pastors such as Pastors Ralekgolela and Mahlagane, who are still strongly preaching the evangelical message of Ngidi and Bhengu. At the top of the list is Dr Khathide from the Apostolic Faith Mission, who has also authored several books on Pentecostalism in South Africa. He wrote books that emphasise praises and encourage the legacy of Pastor Ngidi. His book titled What a giant of faith (1993) is the exemplar of that. In this book his expression of Ngidi comes from a real situation he had observed unfolding.

Most of the social and empowering initiatives of the township societies, especially from the driving powers of such ministries are strongly determined by the background in the former paragraph. Yet, as I have shown in the previous parts in this clause, the contemporary autonomous ministries peppered with the foreign mushrooming ministries have added other dimensions such as anointing with the holy water, olive oil and unusual ways of garnering money from the people indiscriminately in the figure of the tithe (abusively) to enrich themselves. We have stated this seeing as the money piled up is never ploughed back to fend for the members and the community of the poor at large. In the following section we will look into the state of the Tshwane urban Pentecostal churches operational strategies.

It was in early 1986 at the Workers Council of the AFM of SA where a statement was issued to reject the system of apartheid based on racial discrimination. That the black section of the AFM of SA stand for justice and equal opportunities for everybody in all aspects of life, but with special reference to education, economy and politics. They were reacting against all violence, be it institutional or reactional as a way of solving social or economic problems. They also urge a dialogue and discussion in solving societal problems and political problems at every level (Burger \& Nel 2008a:240241). This was a refining point of unity of the church ordered in 1983 from the old order to the new one. The importance of that merger was the allowance to amend the composition of the church on equal say basis.

The black section experienced development that were in many respects unique. As a daughter church it was expected to take the pronouncements of Spiritual Committee, subsequently named the Committee for Doctrine, Ethics and Liturgy. Earlier issues, including marriage by Christian rites, communion, church emblem, clothing, Godfathers and godmothers, initiation schools, children born out of wedlock, secret societies, speaking in tongues and bride veils (Burger \& Nel 2008a:241-251). All of these were to be revisited for assessment.
It was through in 2008 that the black section of the AFM of SA also decided to write a book edited by Molobi and Chikane (2008), published by the CB Powell centre at UNISA on the missing link of their history, which the books of Burger and $\mathrm{Nel}$ (2008b) does not account for in detail. Such a volume was printed under the title: 'An oral history of the South African Apostolic Faith Mission: A missing link of black historical discourse (1908-1960 onward)'. These records contain valuable data, not just about the history of the AFM of SA from the snowy side, but the black section has also been researched and the script will be revised shortly.

\section{Life of the urban Pentecostals}

There are a number of experiences in the urban church centres. Some of the churches are bigger than others. In the black townships church memberships range from small cell groups or home churches as some are called to a thousand members in huge churches. These churches are served by members of different economic status others seemed to be well to do whilst others of a lower division position. It is interesting that none of the members portray an image of being better than the others. Bernstein and Rule (2010:117118) visited the Rhema Bible Church in Johannesburg and analysed the unfolding events $\$ 1.40$ in the same church in the United States of America (USA). Standing in the churches in the mission field wanted to shape up and prosper like their foreign prototypes. Many of the songs were similar to those of churches in the USA. New members are welcomed with excitement. Messages could be downloaded onto cell phones from as little as R10. This is another style of fundraising for the church.

A few years ago, my friend of a very poor background, visited the same church, and he told me that whilst they were praying assurers came too close to him whilst he was praying with his eyes shut and put alms money in his pouch. He stated to me that the church gives to the poor and it is a good church. In Pretoria similar churches are experienced in the city and they operate in the same manner.

In Hillbrow, there was another church in a densely populated high rise inner-city suburb. This was occupied by white immigrants until in the 1980s, and had a continental flair, hosting the city's best bookstores, music stores and first all night eateries. The country now struggles to make do with the influx of the people from Nigeria and the Francophone nations of central and West Africa who often live in overcrowded apartments. The streets are dirty, middle class shops have been substituted by much smaller shop catering for a different business.

\section{The urban ministry as event}

The urban church must draw people through different services. It should be seen as a source of stability, integration and prayer. The parish should be a gravitational pull on its surrounding, but not overwhelmed by any residential area of the micro-environment. It should be a house of the church that beckons to people and welcome them. It is not 
the only situation where the gospel is celebrated in worship, but a situation where Christians help the church meet its entire urban mission. It needs to bear a physical existence not only as an elegant seat of worship, but a readiness of the community centre, a multipurpose building. This is the place in which relationships are created, resourceful people are trained and services offered. It bears to be a source of reflection, prayer, spiritual development, stimulation and renewal (Shorter 1991:76).

As much as cell groups and home visits are performed regularly during the week, popular literature is also applied to supplement moral correction and spiritual encouragement. Such literature is found virtually in all Christian bookstores and others. They can also be ordered electronically. Just to highlight some of the themes in those records, the following paragraphs are examples of those.

The books like Teach your team to fish by Laurie Beth Jones (2002); Natural church development by Christian, Schwarz, and Schalk (1998), and The Bondage breaker: Overcoming negative thoughts, irrational beliefs and habitual sins by Neil Anderson (2000).

There are so many of these kinds of literatures written by celebrity preachers. They too receive their messages in audiovisuals and other various electronic devises. Bible concordances also provide novel ways of interpreting and supplying the biblical messages, often without caring about the formal Western key instruments of theologising. Western Reformation and other Western histories are no longer a factor to the level forms of Pentecostalism. Perhaps spiritual contextualisation is the central event. The modern preaching style brought by immigrants in and outside the continent has taken the people by chagrin.

The previously mentioned literature, coupled with the Pentecostal church services impacted their lives tremendously. Pentecostals feel did not oblige to follow the use of catechisms given that they have not written one. They rely largely on the literal interpretation of the Bible for spiritual upliftment. Most of the pastor's duties will be to set up for the Sunday sermons and other important meetings or travel to another congregation to teach or lead a healing ministry session. Pentecostal ministers of religion are mostly taking second jobs, as their churches are commonly unable to yield them the living wage.

\section{The church as a social work}

Spiritual values cannot be preached without practical material involvement in everyday life of the church members. Evangelisation has a necessary social dimension, seeing as one of its objectives is to gather people into a community that is the Body of Christ. When poor people are cared for by the church of Christ, they will love support it. The message of salvation is the message of integral human liberation and progress. For this reason, the first task of the church in the city is to help people to better their quality of material as well as their social livelihood (Shorter 1991:77).

Christ Glorious Ministries, pastored by a Malawian preacher, meets in a conventional edifice, and the pastor claim to own a fast developing congregation. His services are in English and his pastoral work covers many areas, including finding jobs for congregants in the area where unemployment exceeds $30 \%$; talking about HIV and AIDS and sending people to the city clinic across the road for ant-retroviral treatment. On the topics of abortion and gay relationships, he pronounced that these were not sermon topics, but rather secret discussions with people who has problems in those expanses of life (Bernstein \& Rule 2010:117-118).

\section{Urban social integration}

We can mention the formed cell groups to explain this subsection. Cohesion is important; therefore, to advance it will help with unity in the church. The weekly meetings in small groups serve to welcome the new members and not just share the truth of the Bible, but to also get to know each other better. Cell groups are attached to local urban or townships not to supplant the church or church attendance, but simply to remain small and facilitate personal connections. They pray and eat together and cultivate a certain degree of social cohesion. Cell group for many is a regular meeting of some members' circle of acquaintances. Therefore, as a rule, they have to be 12-20 in number and if they grow larger they will separate into a new cell group. They meet once a week, mostly on Wednesdays. Their social network makes it easier to get through the day in modern urban life. Even those with few social contacts are in the fellowship of the like-minded people at least once a week (Berger \& Redding 2010:46).

Pastors must identify with different ethnic groups and if possible, pastoral teams must cater for several vernaculars. According to Shorter (1991:81) this is important to see the robustness of different cultures in urban regions. The aim of considering different cultures is to convert cultural pluralism into genuine multiculturalism. It is not enough for ethnic cultures to be juxtaposed in close proximity (cultural pluralism), but at that place must be a communication in between them. They should coexist in a state of complementary. Through experiencing other cultures with a certain point of shock, people are led to cooperate in spite of differences they feel. Whilst in that respect may be a standard of cultural loss, nevertheless cultural identities are maintained through dialogue and cultural enrichment.

\section{Urban mission of the church}

Salvation in cities underlines the humanities and enhances positive human values of urban life. These are the values that enable human beings to transcend the human condition and to live the true life that is hidden with Christ in God. Cities are places of human collaboration and initiative, where gifts can be developed for the good of others. It is a space of freedom and individual autonomy. The Church promotes 
these things by revealing their spiritual dimensions. It gives conspicuously human existence of the town a soul. Human beings are helped to utilise their freedom responsibly and to assure that their self-centred networks of relationships do not injure the rights and claims of others (Shorter 1991:84).

The urban mission of the Pentecostal churches focuses much on tent making and church setting. Given that the structural pattern of these churches does not differ much what is practiced in the rural areas is more or less the same as what is served in the urban regions. It implies that some pastors are conscious enough to learn the gospel truth to their mother countries. In other language, there will be some kind of financial backing from the urban church to specific rural regions in the form of commission work. In Pretoria, there are groups formed to serve the mission work in Mozambique and Swaziland. The following segment will be on how the poor people rate the Pentecostal churches in the towns.

\section{Squatter camps}

The townships of Tshwane include Atteridgevville, Mamelodi and Soshanguve. There are also other townships stretching on the outskirts of Soshanguve, such as Mabopane, parts falling into Winterveld and a few more others emerging at various spots in and around Pretoria. These townships are mainly occupied by black people. Lately, we have witnessed a number of white people squatting in similar ways and yet beginning to hold out in the black townships.

The Pentecostal churches or their cell groups are found all over the townships with the message that promises stability and a sense of community for the homeless. With no official demarcation of land, neighbours must share a courtyard and be groomed to offer up any space if a new house needs to be set up. Vegetable patches are carefully nurtured, usually by women and children of the community as the men are often away at work (Shacks and shanty towns n.d.: 11). Several of my sources have told me that they want to make life as normal as possible for a more honest livelihood.

There are children to be confirmed and a form of family spirit is necessary to provide hope to them. Children are attending schools in the neighbouring sections of the townships and some have grown up to become successful and could purchase a decent home for their parents when they are finally employed after completing school. Turning up with few material assets, it is more often children's playful imaginations that will keep them engaged until their parents call them in for the evening meal (Shacks and shanty towns n.d.: 12).

There are ministers fraternal to which new planted churches are introduced to the forum. The forum has representatives from all the churches that exists in the country, for instance, in Atterigdeville squatter camp, they meet once a month or when there is a challenge that needs pastoral attention. This was necessary for them to know each other well, even to which faith group they belong. There are of course church members who attend their church services outside the squatter areas into the main townships or even in town, but that is at individuals' discretions.

\section{The poor people's ratings on Pentecostal churches in the townships}

Pentecostal churches are not strange or foreign churches in the townships. They originate from there and form large numbers of membership from the societies in which they exist; because they are desperate they need hope and encouragement their lives. To worship God is in the lives of the destitute. Now what do Pentecostals offer to them?

Being born again lead to disputes with parents over the rejection of traditional customs such as the role of traditional medicine in favour of faith healing. As a consequence, being reborn has led to an improvement in health and even spontaneous healing. Anderson and Otwang (1993:117) showed that most of the Pentecostals survey in Soshanguve believed in the Pentecostal manifestations: He recorded that nearly $82 \%$ believed in the casting out of demons, whilst $84 \%$ in the speaking of tongues. The grass roots in Soshanguve believe that misfortunes often take the lines of demons that pester them and steal from them. Pentecostal believes they can make out anything in faith through Christ's name.

On healing, for instance, HIV and AIDS, they believe that abstention is the lone means to prevent AIDS, whilst some felt that God could cure it. A routine of them regarded AIDS as a divine punishment for immoral conduct. Some mentioned how they had sacrificed time to attend workshops and read information helping to educate them (Bernstein \& Rule 2010:104).

\section{Financial support strategy}

It helps many to manage their income as a tithe. Some people have claimed that they stopped drinking and been freed from racial inferiority because they were black. Some were assisted to perform voluntary work in their communities after conversion (Bernstein \& Rule 2010:103). They set out by assisting in handing out food parcels to the poor and prayers and coaching children in various fun activities.

Pentecostals offer a protective social capsule that enables the individual to mitigate the negative forces in the life whilst spurring on the positive. As Peter Berger describes it (Bernstein \& Rule 2010):

As long as the individual can indeed find meaning and identity in his private life, he can manage to put up with meaningless and dis-identifying world of the mega structures... The situation becomes intolerable if home, that refuge of stability and value in an alien world ceases to be such refuge - when say my wife leave me, my children take on lifestyles that are strange and acceptable to me, my church becomes incomprehensible, and my neighbourhood becomes a place of danger, and so on. (p. 105)

Pentecostalism also provides some material conditions for individual success. The support and referral networks offered by the congregation adds to people's opportunities and career prospects and provides a safety net for those going through a crisis. These churches often hold in many 
organisational units for youth outreach, as well as home cells with the small members gathering together outside normal church hours. These organisational structures offer ample opportunities for people to become involved in leadership and administration.

More than $50 \%$ of the members of the Pentecostal churches in Tshwane acknowledge that their churches have helped them to improve in health, family lifestyle, being more assured, good cooperation with other people, with financial issues or job opportunities showing up. For illustration, the AFM of SA has developed different empowering departments to serve not only the members of the church, but a community of impoverished people as well. They have opened the department of welfare, teaching, children and sisters fellowship. All of these departments are active and supportive not only to the members of the church, but also the wider community.

People who may have come from a rural, traditional background learn telephone skills, financial planning and how to organise small functions, hold meetings and deal with workplace conflict (Bernstein \& Rule 2010:105).

Being reborn has led to an improvement in health and even spontaneous healing. It helps many to manage their income as a tithe (Bernstein \& Rule 2010:104). Tithing presents a similar phenomenon. The requirements to tithe $10 \%$ of one's income every month forced people to begin calling back about how they apportion their income and about ways to manage their money. Some pointed out that tithing compelled them to embark on using stop orders; a simple financial instrument that can be used for savings and investments.

Domestic violence, child abuse, adolescent pregnancy and child-led families are totally common in South Africa. The banishment of alcohol, drugs, extra-marital sex, domestic violence and crime are the most clearly articulated views from Pentecostal quarter. Social fabric also underpins economic development and growth.

The world of small businesses is the best means to spur an economic development and business creation in South Africa, and the Pentecostal ethic of hope, personal representation and responsibility could be the training ground for such startups (Bernstein \& Rule 2010:106).

Pentecostalism moral codes and propensity to make stronger families would also assist the evolution of minor enterprises, which are often family-run in the training world. The improvement in household life and cessation of drugs and crime is very clear amongst them. Growth in entrepreneurship, the consolidation of democracy, political reconciliation, education and skills developments and health improvements could also be possible outcomes of typical Pentecostal behavioural patterns, but are mediated by other processes that pull in their results more certain (Bernstein \& Rule 2010:106).

\section{The motifs of their Christian mission}

The common aim of the traditional Christianity has been the converted, eschatology, church planting and philanthropy (Bosch 1991:5). One should not forget the perspectives from which these churches have developed in that they are not the same. In a squatter camp, for example, a theme of freedom from mental slavery is relevant. Youth need to be instructed to go beyond perpetual dependency and be rid of the idea that they should be used by a knob. Calling for the teaching of Jesus as seriously as those of Marx, Slovo and Mandela and in practice caring for the poor is important. According to Bernstein and Rule (2010):

The affording churches must contribute to school or university fees of its members, care of HIV/AIDS patients and food for poor people in the community. He said 'We are here because we love Jesus and this means that we must love the poor. (p. 102)

The story that encourages this is that the Pentecostal messages encourage self-worthiness and positive engagement with life. Most Pentecostals oppose pornography; freedom of choice promotes abortion; freedom of religion promotes idolatry; and non-discrimination on the ground of sexual orientation results in sodomy (Bernstein \& Rule 2010:103). The preaching and worship is designed to attract, entertain and ethos is highly voluntary.

The Pentecostal Charismatic churches have a fundamental character based on the stories of origin with the influence from the biblical and Western missionary exponents. Yet the Pentecostal message is different from modern communication of preaching and homiletic theory seeing as it does not get its message alone from there, but also from Homiletics and hermeneutical principles founded in the scriptures.

The following verses, although used in all churches irrespective of doctrinal traditions are worth to be mentioned:

Now the sons of Israel had done according to the word of Moses, for they had requested from the Egyptians articles of silver and article of gold, and clothing, and the lord had given the people favour in the sight of the Egyptians, so that they let them have their request ... (Ex 12:35)

In all things I have shown you that by working hard in this manner we must serve the weak and call up the word of the Lord Jesus, how he himself said, and 'It is more blessed to break than to receive.' (Ac 20:35)

Each one must give as he has decided in his heart, not reluctantly or under compulsion, for God loves a cheerful giver. (2 Cor 9:7)

\section{The shape of churches in urban areas and Pentecostal churches in the townships}

I employed a combination explanation of the urban areas to demonstrate how these churches function in the cities and the towns. It should be clear that at the time of writing Pentecostal and Charismatic churches are not presently foreign mission churches. They are churches with a membership that emerged from within desperate township situations. Thus, they are to be regarded as part of the township community, seeking not only to facilitate others to endure but also themselves. These 
denominations comprise of members who are strangers to each other, they have just coincidentally met in a church and set off a friendly relationship. The message of the preacher or the rector of that church and the sermons preached forms the opportunities for friendships.

We can conclude that in the townships, mostly desperate churches are attempting to help desperate people. This is perhaps a very significant aspect of the church establishment for permanent bonding. These churches came into being as a result of not only poverty as Ntshumaelo (2005:16) puts it: 'With a view of the rapid growth of the population, nearly $70 \%-80 \%$ of the South African population is poor and outside the Christian faith.' To my observation it is not only poverty that determines the desperation of the township dwellers alone. In that respect are people who came to stay in squatter camps to look for job opportunities.

\section{The backyard Bible study ministries}

The backyard Bible study ministries are equivalent to what is commonly recognised as the home cell groups. I have attended some of such home cells and it was remarkable as members are praying for each other. They also fend for each other into joining the social clubs like burial societies and groceries supplying clubs and financial support, like donating a different sum of money circled from members of the group to the next until the round is filled in. This procedure is often run over a period of twelve months. Interesting as even those who are faring from far outside South Africa formed such groups and are stringently monitored to make certain that if any crisis occur, they are able to transport the diseased back home in cases of death. The Malawians are very picky with this because they believe if that is not done the spirit of the deceased will haunt the families back at home in Malawi.

Bible study amongst the Pentecostals in general saturated with gospel praises and worship songs and the sharing of encouraging scriptures, particularly about the well-being of the members. The biblical verses like Galatians 6:9-10 that reads: 'And let us not be weary in well doing: for in due season we shall reap, if we faint not.' The other important and constantly mentioned verse is John 13:34-35, which reads: 'A new commandment I give unto you, that ye love one another; as I have loved you, that ye also love one another.'

The message of caring for one another is engaged very seriously insomuch that not a fellowship is developed, but some groups are bonded into extended families. In addition, Pentecostals vary from the mainline to the African Indigenous groups. This article is attempting to present a perspective that cuts across them all. The thought of viewing the Pentecostal churches as the social worker is really noteworthy. These churches are regarded by many of their members as the caring communities. Caring ranges from spiritual encouragement to material support in smaller scales. Even though members do not have money, it is hardly viewed that way during their services. They are encouraged to pay whatever money is expected to be donated. Probably taking courage to do that from the poor widow offering her last cent (Mk 12:42). Many of the Lutheran, Calvinist and Catholic traditions view that as ridiculous, but from the Pentecostal Chrismatics it is the way of learning to support oneself through the help of others as well.

\section{The shape of the old black townships}

The township houses were meant to host the workers slightly away from the industries of their employment. During the apartheid time these homes were constructed in a very awkward architectural style. Homes were constructed in such a way that sections of next-door neighbours were overlapping to the other family. When revamping the house, they built by adding single or two rooms to make the whole family comfortable, raise tensions with next-door neighbours because they will feel that portion of their space is stolen. The present local municipality is unable to work out that problem. It is entrusted in the hands of the planners and the builders to negotiate such spaces with the two families. This problem is known as the sharing houses (The Start 04 June 2012).

Township yards are small but many landlords will squeeze tenants in order to collect more rentals for survival. Tenants themselves have problems of their own; if one does not pay the rent consistently, the stand owner will simply cut their electricity. There will be fights amongst such families, which may finally result in violent acts that may trigger a wider revolt in the country. In most cases, church members through cell groups are assisting in bringing people together in spots like that Pentecostal churches are seen as very kind churches which don't just pray for the people but unite them as easily.

The trouble is that squatter camps are not just in the black townships, they are likewise set up in the city centre in open places. They congregate in large numbers, for example the Shembe divisions that are found in great numbers in and around Tshwane. Some churches are said to be Pentecostal the way their fellowship. Pentecostals are growing in numbers and having the bulk of lower class people, intending that they too call for help against poverty and homelessness.

\section{Conclusion}

Based on this entire discussion in spite of areas, the Pentecostals are also worth blaming because some are helpful and others are not. Some excluded families are being supported; not only spiritually, but also materially. They are being encouraged to trust God so much that their lives may improve. In a way, they also support the government in addressing social issues which are challenging. The reason of immigration could be viewed in a different perspective for example their positive contributions with new and the strange experiences such as church planting that are capable to generate finances to sustain the destitute. They also assist families to redefine family models that were misplaced in the post 1976 riots in South Africa. The decreases of the substance abuse like alcohol and drugs by conversion are some regions 
they are powerfully concentrated on. Lastly, most of the Pentecostal members are self- supporting and enduring, not necessarily that they have money, but that they are confident in managing things.

\section{Acknowledgements \\ Competing interests}

The author declares that he has no financial or personal relationship(s) that may have inappropriately influenced him in writing this article.

\section{References}

Albers, H.H., 1974, Principle of management: A modern approach, Library of congress in publication data, London.

Allie, M., 2014, 'South Africa's townships - a magnet for entrepreurs', BBC News, viewed 03 July 2014 from http://www.bbc.com/news/world-africa-27141581

Anderson, N., 2000, Bondage breaker: Overcoming negative thoughts, irrational beliefs and habitual sins, Harvest House Publishers, Eugene.

Anderson, A. \& Otwang, S., 1993, Tumelo: The faith of African Pentecostals, University of South Africa, Pretoria.

Berger, P.L. \& Redding, S.G., 2010, The hidden form of capital: Spiritual influence societal progress, EBSCO, Anthem Press, London.

Bernstein, A. \& Rule, S., 2010, 'Flying under South Africa's radar: The growth and impact of Pentecostals in a developing country', in P.L. Berger \& S.G. Redding (eds.), The hidden form of capital: Spiritual influence societal progress, 103-118, EBSCO, Anthem Press, London.
Bosch, D., 1991, Transforming Mission: Paradigm shift in theology of Mission, Orbis, Maryknoll.

Burger, I. \& Nel, M., 2008a, The Apostolic Faith Mission of South Africa 1908-2008, Special Gift Edition, Apostolic Faith Mission of South Africa, Centurion.

Burger, I. \& Nel, M., 2008b, The fire falls in Africa, Christian Art Publishers, Vereeniging. Econ 3x3, 08 July 2014, viewed from http://www.polity.org.za/page/econ3×3 Hollenweger, W., 1988, The Pentecostals, Hendrickson Publishers, Peabody.

Investopedia, n.d., Blue collar, viewed n.d, from http://www.investopedia.com/ terms/b/bluecollar.asp

Johnson, R.W., 2012. Lawrence Schlemmer (1936-2011) attribute, Emeritus Fellow, Magdalen College, University of Oxford, viewed 06 July 2012 from http://www. tandfonline.com/loi/rssr20

Jones, L.B., 2002, Teach your team to fish, Three River Press, New York.

Khathide, A., 1993, What a giant of faith, Gospel Publishers, Johannesburg.

Molobi, V. \& Chikane, F., 2008, An oral history of the South African Apostolic faith Mission: A missing link of black historical discourse (1908-1960 onward), CB Powell Centre, UNISA, Pretoria.

Narayan, D. \& Petesch, P., 2002, Voices of the poor from many lands, Oxford Press, New York.

Ntshumaelo, M.P., 2005, Towards a relevant ministry among the poor, viewed 28 October 2005 from http://upetd.up.ac.za/thesis/available/etd-10282005120904/unrestricted/01chapter1.pdf

Ragoonath, A., 2004, Preach the word, Agape teaching ministry of Canada, Winnipeg. Schwarz, C.A. \& Schalk, C., 1998, Natural church development, Church Wise, Pretoria. Shacks shelters and shanty towns and shanty towns, n.d., Art Publishers, Johannesburg.

'Sharing houses poses problems', 2012, The Star, viewed n.d., from http://www.iol. co.za/the-star/sharing-houses-poses-problems-1.1310712\#.VDumUxZyWiU

Shorter, A., 1991, The church in the African city, British Library, London. 